\title{
Article
}

\section{Household networks and emergent territory: a GIS study of Chumash households, villages and rock-art in South-Central California}

Robinson, David Wayne and Wienhold, M

Available at http://clok.uclan.ac.uk/15376/

Robinson, David Wayne ORCID: 0000-0002-0729-5011 and Wienhold, M (2016) Household networks and emergent territory: a GIS study of Chumash households, villages and rock-art in South-Central California. World Archaeology, 48 (3). pp. 363-380. ISSN 0043-8243

It is advisable to refer to the publisher's version if you intend to cite from the work. http://dx.doi.org/10.1080/00438243.2016.1185378

For more information about UCLan's research in this area go to http://www.uclan.ac.uk/researchgroups/ and search for <name of research Group>.

For information about Research generally at UCLan please go to http://www.uclan.ac.uk/research/

All outputs in CLoK are protected by Intellectual Property Rights law, including Copyright law. Copyright, IPR and Moral Rights for the works on this site are retained by the individual authors and/or other copyright owners. Terms and conditions for use of this material are defined in the policies page. 


\section{Household Networks and Emergent Territory: a GIS study of Chumash households, villages, and rock-art in South-Central California.}

David Robinson, Senior Lecturer in Archaeology, School of Forensic \& Investigative Sciences, University of Central Lancashire, Preston, United Kingdom, PR1 2HE, Phone: (+44) 01772 893756, Fax: (+44) 01772 894981, DWRobinson@uclan.ac.uk

Michelle Wienhold, Geographic Information Systems Analyst. IIHR - Hydroscience \& Engineering, Iowa Flood Center, 305 Trowbridge Hall, University of Iowa, Iowa City, IA 52242, +1 319-353-0764, michelle-wienhold@uiowa.edu 


\section{Abstract}

Elite households of the Californian Chumash have been studied in order to understand the development of Late Holocene hunter-gatherer alliance networks. Equally, models of what has been termed 'tribelet territories' have been used to describe land ownership within larger Californian concepts. Surprisingly little research has explicitly addressed issues of how such territories may have developed. In this paper, we turn to DeLanda's (2006) philosophy of social complexity to consider how Chumash households may have underpinned the development of tribelet territories and the political implications for their articulation with wider alliances. Importantly, utilizing Geographic Information Systems, we analyse potential mobility patterns in relation to households, villages, and rock-art locales in a case from the Emigdiano Chumash. The results suggest that the painting of rock-art was imbricated within processes of territorialisation, and that the local placement of art reflects which villages were home to particularly high status households. 


\section{$\underline{\text { Introduction }}$}

The study of Chumash households in Southern California has a long archaeological pedigree (see Rick 2007 for overview; see also Gamble 1995: 2008; Graesch 2001; Shumacher 1877). Ethnohistoric work has detailed how elite households developed and maintained their status through regional intermarriage networks in which the control of exchange and ceremonial relationships underpinned a hierarchical structure to Chumash society (Johnson 1988). So, archaeological work of households has often explored the potential material correlates of this hierarchy by investigating the deposits associated with Chumash houses. Chumash society at the time of European contact was hierarchically organized, with elite households from different villages intermarrying to create a political ruling class. These inter-household networks extended throughout the Chumash speaking population far into interior regions (Robinson 2011). Elite households orchestrated trade and ceremonial events, controlling the circulation of subsistence and wealth items that underpinned their prominence both in daily practice and in conspicuous display events (see Gamble 2008). Research has focused on the extensive influence of bead production and exchange relationships of certain coastal households which enabled the acquisition of wealth and status; particularly influential households enabled some villages to become politically powerful players within alliance networks. Few studies have looked beyond the house itself to consider how the local landscape may have specifically contributed to wealth strategies of individual households nor considered how the local terrain and its resources may have enabled certain villages to gain prominence over others (see Kennett 2005, 180-181). To do this requires a consideration of the political dimensions of individual households and villages, and how processes of territorialization may have reflected the relative status of elite villages.

Most archaeologists view territoriality as an emergent outcome of sedentism and population expansion (Rosenberg 1998) and conflict over resources (Baker 2003). Huntergatherer studies of ownership often emphasize that territories are typically not bounded entities, but point specific or nodal, either in terms of specific places or resource patches within a wider orbit of logistical movement (Zedeño and Anderson 2010; Robinson et al. 2012). In California, Kroeber $(1925,830)$ coined the term 'tribelet' to describe a relatively unique form of land ownership based upon a restricted localized transhumance pattern of seasonal movement. In Kroeber's model, a tribelet was composed of a principle village, which served as the political 
and logistic base to access resources in adjacent lands. There may be subsidiary hamlets or seasonally occupied locales that were included within the tribelet territory. Kroeber $(1955,306)$ estimated "an average population, for each of the autonomous units that owned a specific territory, of around 200 to 300, and an average territory of more or less 500 square miles. This in turn means a tract measuring around 20 by 25 miles, or perhaps 15 by 30 to 35". In more densely occupied areas, studies suggest much more compact tribelet territories, some perhaps as small as two square miles in the San Francisco Bay area (Cordero 2015). Territorial ownership beyond the actual settlements in Kroeber's view was based upon the usage of "wild" resources. However, as Lightfoot and Parrish (2009, 76-77) show, much of Kroeber's model has come under criticism for not recognizing that larger political linkages existed for many Californian societies (such as the Chumash); even so, they do not discard the term nor shift focus away from settlement systems, noting how tribelet territories often followed drainage systems allowing access to different ecotones from lower to higher elevations. In their view a dispersed settlement system would have facilitated the management of the local environment, while arguing for a model that "deemphasizes clear-cut polity boundaries in favour of a networked fabric of social relationships radiating across the landscape" (Lightfoot and Parrish 2009, 36). Bettinger (2015) more recently has delved into the relationship between marriage networks and land use practices in the formation of tribelets. He argues that "Neighboring patrilineal-patrilocal bands would necessarily have drawn wives from each other and by virtue of that been motivated to help provide for each other's defense. Tribelet organization simply formalized this de facto reality. Separate patrilineal bands threw in together for common defense while retaining their separate identity, resource patches, and private food store" (Bettinger 2015, 136). However, while Bettinger's primary data does not include the Chumash, he recognizes that they practice a mixed post-marriage residence pattern whereby males chiefs were patrilocal while the rest of society was primarily matrilocal (derived from Johnson 1988) (Bettinger 2015, 156-159).

In some regions, such as the Chumash, it appears that multi-village 'federations' or 'provinces' developed beyond tribelet territories in the creation of alliance networks based upon co-operation between elite households. Over 160 Chumash villages and their locations have been documented (Applegate 1974; 1975; King 1975: McLendon and Johnson 1999). The role of the village as an axis mundi in Chumash life is central to understanding wider social geography. King (1976) noted that trade crossed ecological boundaries thus acting as a buffer 
against local shortfalls, with strategically placed villages having an advantageous position. Johnson's (1988) research using historical mission records shows how regional 'capital' villages with dominant households were located at these strategical locations while promoting their status though marriages with other elite households. Members of dominant households were usually part of the 'antap institution, a region wide group that controlled ceremonial, religious, and ideological events across Chumash territory: as Gamble $(2008,56)$ states, "Chiefs and their families were required to be members of this prestigious group." Developing ways to understand the dynamics of territorialisation within local contexts such as with tribelets and investigating how processes of territorialisation played a role in the emergence of larger polities such as Chumash alliance networks are crucial in further understanding the dynamics of complexity and the agency of households in the extended landscape. DeLanda's (2006) philosophy of social complexity is employed here to consider how Chumash households may have underpinned the development of tribelet territories and the political implications for its articulation with wider alliances.

\section{Assembling territories}

DeLanda's (2006) approach to social complexity models processes of territorialization and deterritorialization within the context of assemblage theory. Territorialization is a synthetic process whereby component parts articulate with one another in the formation of an assemblage. This is a scalable concept. As DeLanda (2006) states, social assemblages emerge through informal face-to-face encounters in specific places, or through interpersonal relationships that define communities such as neighborhoods or towns, or become defined organizationally through institutions emplaced in particular buildings, on out to formal governments and their jurisdiction over provinces or towns with formal boundaries. Territorialization is the term coined to define the process whereby the participants in a given situation come together, and thus gives a definable character or identity to social assemblages. Fundamental to this process is the copresence and internal homogeneity of the relationships between the component parts: the 'parts' are of course the human actants, but also physical places and material culture that plays an active role within facilitating social interactions. The breaking down, or decomposition, of that internal homogeneity, is a process of deterritorialization. Importantly, a central tenant of assemblage theory postulates that a component within any assemblage may be "detached from it and plugged 
into a different assemblage in which its interactions are different" (DeLanda 2006, 10): this idea, that parts can have potential external relations to other assemblages, is termed "relations of exteriority". So, assemblages ultimately undergo processes of deterritorialization largely because the components of an assemblage can enter into different relations within other assemblages. From an archaeological perspective, this is very important as it allows us to analyze how territories may change sequentially in a piecemeal fashion by looking at how different components within any society's mode of territorializing may be subsequently appropriated.

Certainly the house was the primary locus of activity within typical Chumash life and formed a central node in any personal concept of territory. Chumash houses typically were semispherical pole-and-thatch constructions, from 4 to 12 meters in diameter, occupied by a nuclear or small extended family (Hudson and Blackburn 1983; Gamble 1995). Features typifying a Chumash house include clay or plaster flooring, circular post holes for the superstructure and partitioning of the interior, a hearth, and storage features such as pits (Gamble 1995). Excavations by Gamble (2006, 133) at a house at the village of Helo' confirmed that activities were directed by the architectural space of the interior. So, the first scale of territorialization can be seen within the confines of the house itself. Identifying specific elite residences has had mixed results (see Arnold 2001, 290; Rick 2007), with the firmest evidence coming from island contexts (see Graesch 2004).

Moving beyond the house was the larger village itself. Chumash villages vary in size from only a few houses to several dozen (Brown 1967). While coastal village sizes could exceed 1000, populations within the inland and interior were smaller, with the largest estimated site being Soxtonokumu' with about 200 individuals (Horne 1981). A reliable water supply was typically provided by a perennial stream and/or spring nearby. Each village would have one or more sweathouses for bathing, socializing, and ceremonial purposes. At times, a village may have an accompanying ceremonial enclosure, called the siliyi $k$ (discussed below). Burial grounds marked with painted poles or decorated stone slabs were often located close or even adjacent to the village. Large flat areas were used as gaming fields, especially for the athletically vigorous and skilled "hoop-and-pole" game. Acorn and other granaries were located close to the 
houses: these houses were often huddled together, sometimes only a couple of meters apart, set in orderly rows.

A village leader was called a wot in Central Chumash languages, capitán by the Spanish, and "chief" in archaeological and anthropological parlance. Marriages to chiefs were the primary exception to the pattern of monogamous matrilocal residence: a chief typically had more than one wife, each of whom would move from her natal village to that of the chief (Johnson 2001, 54). Not every village had a recognized chief, but a paramount chief residing at a principal village may have served political, economic, and ceremonial roles as the head of a group of villages, collectively termed a "province" or "federation" (Johnson 1988). As Johnson summarizes $(2001,54)$ :

The towns where the chiefs resided often had more geographically extensive kinship relationships than did other villages, and the chiefs' families themselves intermarried with other chiefs' lineages and into families that were more geographically distant. These types of patterns underscore the importance of the chief's role in regulating intervillage economic exchange and his need to solidify economic and political alliances through intermarriage.

In part, it is through this pattern of intermarriage between members of equal status across Chumash territory that a system of social ranking came into being with status at least in part, increasingly hereditary. On the islands and along the coast, these social relationships strengthened traditional ties associated with cross-channel trade and the acquisition of wealth through chiefly control of the bead economy, with labor at the household level feeding into a network of personal and material relationships stretching into the interior (Horne 1981; Johnson 1988; Robinson 2011). At rituals such as the Mourning Ceremony, or fiestas such as the Sun or Harvest Festivals, the ideology of the Chumash was explicitly displayed in a public manner. Spatially, these events took place close to the domestic sphere- either near or actually within the village and centered upon the fenced circular siliyi $k$ enclosure.

Villages thus are assemblages of certain components: most importantly, the people themselves, but also structures such as houses, sweat lodges, granaries, and enclosures; burial grounds with markers such as poles; a large habitable space with a perennial water supply and a 
geographic location that enabled access and control of the local terrain while also enabling relationships with neighboring villages. Blackburn's $(1975,73)$ classic study of Chumash narratives show how being indoors or within the village space was considered the safest domain to inhabit, but that traveling outward entailed an ever increasing degree of peril the further one went, suggesting that village spaces obtained the highest degree of territorialization in terms of habituated use and indigenous perception. However, seasonal movement required leaving such spaces. Beyond the village would be a series of other locales which would be encountered or visited for varying tasks and amounts of time.

\section{Pictograph K-locales assemblages}

Dispersed across Chumash territory are over 250 confirmed pictograph sites, but there are undoubtedly many more yet undocumented (Wienhold 2014). Pictograph sites are rarely if ever associated with Late Prehistoric Chumash villages but are more commonly associated with important resource areas which would have been visited as part of those seasonal movement patterns. Studies show that the great majority of pictographs are placed at key locations where intensive food processing took place (Robinson 2007; 2011). These places are known as pictograph K-locales ('K' designating 'Key') as defined by abundant bedrock mortars (BRMs), associated midden, pictographs, and sometimes evidence of storage features such as granary platforms, walled off shelters, or foot/hand holds to access storage areas (Robinson 2006; 2010a). Like the village, a K-locale needed to be within or near to abundant plant resources while requiring a reliable water supply plus a habitable land form; however, the water could be in the form of an intermittent rather than perennial supply, and the habitable space did not need to be as large. Bedrock that was amenable to the making of bedrock mortars was also necessary; in order for pictographs to be made, either rock shelters or vertical faces were needed for the application of pigment. Along with the people, these are the components of the K-locales behind processes of territorialization in these non-village contexts. Indeed, in some respects, K-locales provided a kind of safe haven akin to the village as an aggregation center but in 'backcountry' contexts.

Villages and K-locales clearly were two critically important sites within the Chumash landscape in terms of time of duration of occupancy, numbers of people at the sites, and intensity of use in terms of labor and other habitual activities. All of these are factors that fit well within 
the tenets of assemblage theory in terms of constituting a process of territorialization. We argue that villages and K-locales were the most crucial in terms of the development of an attachment to place and the formation of local group identities across Chumash landscapes. However, what was the relationship between villages and these pictograph K-locales in terms of the process of terrritorialization of localized tribelets and even larger provinces? Catchment, transhumance, and mobility analyses all indicate that Chumash pictograph K-locales were part of a Late Period seasonal round where populations from village dispersed and re-aggregation at backcountry Klocales including those with paintings (Horne 1981; Horne and Glassow 1974; Robinson 2006; 2010a). It is likely that most pictographs would have been made by people from specific village sites derived from the very populations who moved between village and K-locale. Equally, many scholars have argued that the paintings were made by members of the antap (Hudson and Underhay 1978; Hudson and Lee 1984) and may have in part been part of some form of territorial marking (Hudson and Blackburn 1987). It therefore may be inferred that pictographs could in part have been an ideological media projecting an authoritative claim of specific Klocales by members of influential households from specific local villages. To examine how this process and the potential relationship between known villages and pictograph K-locales created landscape assemblages, we compare a series of Geographic Information Systems (GIS) analyses to tease out linkages and patterns of movement within a special Chumash sub-linguistic area.

\section{The Emigdiano Chumash}

Rising from the floor of the San Joaquin Valley, the San Emigdio Hills (Figure 1) are occupied by speakers of an interior Chumash dialect known as Emigdiano. Geologically, these southern hills are a turbulent and complex region of intersecting faults and rapidly uplifted topography. The hills are cut by north flowing canyon arroyos: most are narrow canyons, with their waters spilling out into the southern plain, sinking to become subsurface ground water and feeding the large lakes of the Lower San Joaquin, including Buena Vista and Kern Lakes where substantial populations known as the Valley Yokuts lived (Kroeber 1925; Gayton 1948). Within the hills, geological activity confuses the terrain: side canyons, raised terraces, ridgelines, and other landforms crisscross the north-south drainage systems, either facilitating or hindering movement.

Archeological excavations over the last 15 years have identified changing settlement patterns (Bernard 2008; Grasse 2005; Robinson and Sturt 2008; Robinson et al. 2010). Of note 
are significant Middle Period components at the sites of Pleito and Three Springs dating between about 1600-2000 BP. These two sites are situated within the foothills, and likely the focus of extensive food processing and extended settlement, suggesting that they were principal residences during this period. Circular depressions at Three Springs likely reflects the semisubterranean foundations typical of Chumash houses. These two sites have the greatest amount of over painting within the region, and much of the earlier layers likely date to this period of settlement. However, following the Medieval Climatic Anomaly ( AD800 to 1350), a shift is seen from these foothill sites to larger villages located at the mouths of the major canyons as part of a demographic change within the Emigidiano landscape. Sites such as Pleito and Three Springs continue to be visited, along with a much wider variety of other locations, but no longer appear to be major population centers. This period of reorganization can be characterized as a Middle Period de-territorialization with a concomitant territorialization into the classic Late Period pattern. Rock-art sites were critical components within both of these territories. In this phase of the Middle Period, evidence seems to point to the paintings being placed at the most active locations, therefore constituting a terrotorializaion of the immediate principal residence environs. As time progressed and these sites ceased being intensely occupied, these same images became components of a more widespread mobile land use pattern, removed from central village sites but still occupying a highly visible presence within seasonal movement patterns at places now acting as K-locales. The dynamics of this shift are important: rock paintings became a different kind of component in relation to the larger site assemblage. This can be interpreted as an expression of the relations of exteriority inherent in rock paintings and it is the role of rock-art within the later context and the process of territorialization that underpins possible tribelet organization towards which we now shift our focus.

\section{$\underline{\text { Rock-art \& political authority }}$}

Archaeological survey combined with ethnohistorical documentation has identified probable locations of the three known Emigdiano villages: Matapuan (or Malapwan), Tashlipun, and Tecuya (or Taku'y) (Bernard 2008; Robinson 2006). In order for a territory to be viable, there must be a means of expressing legitimacy in terms of claims over that territory. DeLanda (2006) is clear on this point in his discussion of persons, labour, resources, and the formation of networks. As he states, enforcement mechanisms need to occur not in an abstract space, but 
rather in concrete social entities made up of real interpersonal networks and organizations (DeLanda 2006: 65). Such mechanisms can operate in non-linguistic ways and entail a process termed 'coding' which can move towards solidifying territorialization into a longer enduring entity. This becomes particularly important in the formation of organizations and governments in larger scale assemblages beyond that of the person-to-person. A village and its extended territory such as a tribelet is just such an assemblage. In the context of the relationship between resources and labour, coding as an enforcing mechanism of legitimacy should be recognizable within such processes of organizational territoriality. Visual media such as pictographs can serve as just this kind of coding, either intentionally as overt forms of authority and rights of access, or unintentionally through forms of habitual practices and intergenerational forms of appropriation. Emplaced at key locations where labor practices produced food and material culture, pictographs at K-locales can be seen as a projection of legitimacy at non-village Late Period locations (Robinson 2013c). The outputs of this labor would have provided more than simply sustenance, but produce the very materials (both raw and crafted) which enabled local elites to engage within wider networks. Since forms of territorialization ultimately entail political power, having claims of legitimacy not only would bolster the relative position of those making such claims, but may

have allowed better access to these K-locales. Households and their villages that had differential access to these backcountry K-locales therefore would have had a wider access to important resources as well as critical places for the placement of coding. It may be possible then to investigate how the internal processes of territorialization may have favored the development of political power for particular villages within the Emigdiano landscape.

\section{Isochronic movement and territorial emergence}

For DeLanda (2011), the concept of 'gradients' is central to propositions concerning the emergence of assemblages, and therefore in the context of this paper, territorialization. DeLanda $(2011,9)$ states that "gradients can serve to generate the moving parts of a larger whole" thus conceptualizing gradients as an energy transfer which occurs due to intensive differences in domains as diverse as thermal dynamics to status differentiation in human society: however, there is no reason not to take the term quite literally. The topography of the Emigdiano landscape has a great range of different gradients that alternately affected or afforded human movement within that terrain. Perhaps the optimal way to investigate human movement across 
the terrain is to employ anisotropic analysis whereby directional movement is calculated. This movement can be quantified and therefore visualized in isochrones. Isochrones are defined as the cost of travel where "...the time required to reach this point from the origin is constant" (Herzog 2012: 18). For this analysis, all sites that fall on a specific isochrone can be reached in the same amount of time, while sites that fall within the isochrones would be reached at some time between the designated interval values. The continuous or 'buffer-like' outputs prevent the analysis from being constrained to specific, discrete paths. The advantage here is that it allows alternative means of assessing 'free' movement. Areas of movement are treated as spaces where human agents would have chosen their own path within each time contour, such as switchbacking up difficult terrain. The algorithm for creating travel times is based upon Tobler's hiking function (Gorenflo \& Gale 1990; Tobler 1993) with vertical factors taken from Tripcevich (2009). Tobler's hiking function applies cost to provide a rough estimate of time at an average walking speed of $5 \mathrm{~km} / \mathrm{hr}$ on a flat surface with values that change according to slope and distance (Gorenflo \& Gale 1990; Tobler 1993). For example, a slightly downhill slope would be faster than walking on a flat surface, but the more negative the gradient the more difficult it would become. Varying age, fitness and body types of the people walking are not taken into consideration, but it would affect the outcome.

Research here focuses on the immediate terrain and backcountry areas associated with the village sites and takes into account edge effects within the data by clipping areas with little evidence or no available evidence of archaeological sites. The first outputs are based on a 10m DTM employing 4-hour to 16-hour bins moving away from all three village sites (Figures 2, 3, \& 4). The times represented can be considered within the range beginning at zero from the site and increasing to one-half day (4 hours) up to two days of walking (16 hours) respectively. Walking from Tashlipun a village inhabitant could encounter twelve rock art sites while walking from Matapuan one could potentially reach ten rock art sites within one day ( 8 hours). Tecuya has five rock art sites again within 8-hours of walking. Tashlipun still maintains easier access to more sites based upon its geographic placement as to be expected. Interesting to note, is that access to the Yokuts territory into the San Joaquin Valley to the north is relatively efficient compared to the higher travel cost within the Emigdiano landscape. 
To further understand each villages' potential interaction within the landscape in respect to both the K-locales and the rock art sites, overlap for each of the time bins were mapped up to 16 hours or two days of walking. Figure 5 represents the areas of overlap and/or relative separation between each village during a hike up to 4 hours away from the villages within their landscape. High geographic overlap between Matapuan and Tashlipun is apparent with relatively easy access between the villages themselves and multiple rock art sites. Again, Tecuya is more geographically isolated. Three subsistence based sites (K-locales) are within the mapped areas of movement: one is strictly within Matapuan's isochrone and just outside of Tashlipun's, while another is within an area of overlap between the two sites Finally, a K-locale with seventeen recorded BRMs located at the mouth of Pleito Creek, is within the overlapping isochrone for all three villages.

One day of walking is shown in Figure 6 and again the overlap is even more significant as to be expected. Movement from east to west shows that many of the rock art sites and Klocales would be accessible within this time frame for people residing at both Matapuan and Tashlipun. Traversing through the San Joaquin Valley, people from Tecuya would be able to move down canyon along San Emigdio Creek directly into Tashlipun's immediate sphere of influence.

Figure 7 and Figure 8 represents 12-hours and 16-hours of walking away from the 3 villages sites. The results of two days of walking now completely cover all of the known sites within at least one village's sphere of influence. For the Chumash, as hunter-gatherers, this time and distance effort was likely not considered great, as they would have traveled long distances to the coast for trade and ceremonial purposes (Gamble 2008), yet long distances would have been more costly when returning to a site carrying foodstuffs.

Interestingly, these analyses indicate that Matapuan was highly strategically placed to become involved within backcountry dynamics. Mission records give account that in AD1790, a war chief from Matapuan had enough authority to organize a multi-village revenge party consisting of Yokuts and other Chumash villages to retaliate against the Shnaxalyiwi Chumash village located in the upper Santa Ynez River and included four members from Tashlipun (Johnson 2007). In 1806 the village also was recorded as having the largest population in the region and had control of a subsidiary village (Cook 1960, 245). This indicates that the 
paramount household at Matapuan had significant influence in the area. However, overall Tashlipun takes a dominant role in ethnohistorical narratives about the regions (see Robinson 2006, Chapter 3). For examples, Johnson (2007) details how Tashlipun converts were instrumental as leaders in the famous 1824 Chumash Revolt and how there was rivalry between the chief of Tashlipun and Lake Yokuts. Horne $(1981,116)$ suggests substantial kinship ties with Tulamni and Hometwoli Yokuts indicating alliances across linguistic boundaries. Accounts of Tecuya are less frequent and none suggest that it was a dominant polity.

\section{Least-cost path analysis and entrenchment}

The above isochrone analysis suggests the ways in which movement from village sites may have occurred over time. As Inkpen et al. (2007), Zedeño and Anderson (2010), and Wienhold (2014) have pointed out, these kinds of repetitive movements entrench into what we suggest are quasiformal networks. Over intergenerational time, as households developed relationships with specific K-locales, such patterns of movement may have become more firmly enmeshed into formalized traditional pathways. To investigate the potential entrenchment that each village may have had to K-locales, and to consider deeper the internal dynamics of tribelet territorialization, we performed an isotropic least-cost path (LCP) with a 30m DTM between each village locale and each pictograph site (Figure 9). Since territorialization is most likely to occur where gradients afford easy repetitive access to strategic nodes within the local terrain, by comparing the values of each LCP analysis, the relative ease of movement between each village and each rock-art site can be quantified.

Table 1 shows that of the seventeen pictograph sites located on the Preserve, ten are easier to reach from the village of Tashlipun. The LCP generated from Matapuan runs through three sites while Tecuya has four. Numerous K-locales are further encountered by following the designated paths. Care should be taken not to read too much into this data-simply because a site has a LCP from one village does not indicate that only people from that village made the rock-art. Also, Matapuan and Tecuya are towards the edge of the survey area: more sites may lie outside of Preserve boundaries within these village cost-surface spheres. Future survey and further approaches such as the use of modified Thiessen polygons could provide data to reconsider these results. However, it is notable that ethnohistoric information discussed above 
indicates that Tashlipun was a dominant polity during proto-historic times, and in turn, had a strong centralized geographical position.

\section{Conclusion: Emergent territoriality}

The emergence of territorial entities cannot be divorced from the real world in which they emerged. The physical morphology of the terrain offered a variety of gradients within which the Emigdiano developed over the last 2000 years. The morphology of that terrain may have aided the inhabitants of Tashlipun to maneuver more freely through the landscape - a factor that likely influenced their ability to engage with the backcountry. Most canyons run north-south, opening onto the lower San Joaquin Plain. Going up-canyon, the slopes and elevated ridgelines to the side make east-west movement difficult, and from the isochrone analysis outputs, it is indeed more time consuming. However, three major east-west corridors run against the grain of this topography, facilitating lateral movement (see Robinson 2006; 2010a). Two of these corridors bisect San Emigdio Canyon, allowing Tashlipun inhabitants easier and faster access into their backcountry landscape.

The outputs of the LCP analysis indicate that a majority of pictograph sites are within the Tashlipun sphere of influence, so rock-art may indeed be a reflection of its entrenchment as the major polity: if this is true, lateral movement through the adjacent hills may have facilitated the interlinking of subsistence and ideological practices. Yet, the outputs of the isochrone analysis are not as strongly or discretely distinguished. Within a day of walking from Matapuan and Tashlipun, one could encounter ten pictograph sites and twelve respectively, a considerable difference compared to the LCP of three and ten respectively. While Tashlipun does have a strong geographic advantage in terms of landscape movement and easier or faster lateral access to sites across the backcountry in both of the GIS analyses, walking times indicate that both Matapuan and Tashlipun had geographic advantages, at least in the western Emigdiano region. However, Tashlipun did have a few hours advantage for backcountry penetration. Yet, that may have been all the advantage that the dominant households of Tashlipun needed to secure their status as a major polity within the region. Furthermore, perhaps geographic access into the San Joaquin Valley from Tashlipun (although not explored spatially in this paper) presented major economic advantages, and based on historic records of enmity and rivalry between the 
Emigdiano Chumash and the Lake Yokuts (people to the north), perhaps secured it role as a strong defensive force for the backcountry.

To this point, we can see how potential individual competition between villages interplayed with how the gradient of their localized terrain afforded access to key locations. While evidence suggest rock-art was probably part of Middle Period locales such as Pleito and Three Springs, the making of paintings at these and other K-locales in the Late Period could have coded those access gradients by extending the authority within the village community to that of the rock art locale. If this is the case, here we see relations of exteriority within the territorializing process with the changing possibility spaces DeLanda $(2006 ; 2011)$ speaks of: first, temporally with rock-art from earlier village locales becoming re-assembled into Late Period K-locales; and second, if rock-art was indeed made by members of influential families, power structures at the household level would have translated to landscape in form of paintings. Equally, pre-existing paintings could have been appropriated into mythological narratives reifying ontological postulates underpinning society (see Robinson 2013b).

The isochrone analyses further show that walking away from all three villages within 16 hours creates a strong overlap that interlinks all of the known archaeological sites. Importantly, the K-locales, as major areas of subsistence processing, fall within areas of overlap at all distance bins beginning with a single site at the 4-hour increment. Finding areas that were nearby that also fulfilled specific requirements, such as vegetation for cuisine choice and trade value and also specific geologic attributes, would have made these sites highly desirable. For example, within an 8-hour walk from Matapuan and Tashlipun two K-locales with pictographs should be noted here. The first, Los Lobos is a site with two pictograph loci and 16 BRMs, located in the Los Lobos drainage between both villages. The second, Pond is a site with pictographs and over 100 BRMs located east of San Emigdio drainage. While the specific paths that were traversed are not known, understanding that in terms of time, access to K-locales from either Tashlipun or Matapuan could have resulted in competition of these resources or required specific public acknowledgement of ownership of these sites informing family groups or villages. Even Tecuya begins to encroach on the western sites at high time bins resulting in a growing network between all of the sites within the Emigdiano region. It is within this context of extending authority along access gradients encouraging entrenched movement in the Late Period that each of the three 
Emigdiano villages probably developed its tribelet territory. The observation in 1806 that the village of Matapuan had a hamlet called Napolea (which may be the rock-art K-locale called Santiago) suggests just such a formation.

Finally, the geographic proximity of the villages would perhaps suggest that an alliance network would have developed into a province, likely with a paramount chief domiciled at the dominant household at Tashlipun. Certainly, the raid of 1790 shows just such alliance cooperation between Matapuan and Tashlipun, but it is the chief of Matapuan who orchestrates that event. Further, ethnohistoric evidence shows no strong marriage ties between the villages within the area but rather outside the region (Johnson and Milliken 2010a; 2010b). This indicates relations of exteriority were indeed in effect at least in the historical period, with elite households creating extra-regional alliances - a different form of assembled territorialization. The 'antap institution also provided a transregional form of assemblage that exceeded tribelet territories. Again, if 'antap from elite households were responsible for a good quantity of the rock-art imagery, then the iconography exhibited relations of exteriority by being reproduced in similar forms across multiple Chumash regions. Late Period rock-art and processes of territorialization thus operated simultaneously in different ways (i.e. different assemblages), with rock-art coding local tribelet locations while coding 'antap institutionalization. But this doubleemergence should always be recognized as occurring by actual people who traversed a real landscape, originating within local households and their villages.

\section{Acknowledgments}

We thank Julienne Bernard, Rick Bury, Carole Bury, D. C. Clendenen, Sheryl Clendenen, Michael Glassow, John Johnson, Unika Delpino-Mark, Rick Peterson, Vicki Cummings, James Morris, Dan Reeves, Jack Sprague, and Fraser Sturt. Special thanks to Dan York of the Wildlands Conservancy and the staff of the Wind Wolves Preserve for their permission and kind support for this research. 


\section{$\underline{\text { References }}$}

Applegate, Richard B. 1974. Chumash Placenames. Journal of California Anthropology 1(2):187-205.

Applegate, Richard B. 1975. An index of Chumash placenames. In Papers on the Chumash.. San Luis Obispo County Archaeological Society, Occasional Paper 9: San Luis Obispo, California, pp 19-46.

Bernard, J. 2008. An Archaeological Study of Resistance, Persistence, and Culture Change in the San Emigdio Canyon, Kern County, California. Unpublished PhD dissertation, University of California, Los Angeles.

Bernard, J., D.W. Robinson, and F. Sturt. 2014. Points of Refuge in the South Central California Colonial Hinterlands. In New Perspectives on Spanish Missions in the Indigenous Landscape, eds. L. Panich and T. Schneider, 84-109. University of Arizona Press, Tucson.

Bettinger, Robert L. 2015. Orderly Anarchy: sociopolitical evolution in aboriginal California. University of California Pres: Oakland.

Blackburn, T.C. 1975. December's Child: A Book of Chumash Oral Narratives. University of California Press: Berkeley/Los Angeles/London.

Brown, A.K. 1967. The Aboriginal Population of the Santa Barbara Channel. Reports of the University of California Archeological Survey 69.

Cordero, J.F. 2015. Native persistence: marriage, social structure, political leadership, and intertribal relations at Mission Dolores, 1777-1800. Journal California and Great Basin Anthropology 35(1): 133-149.

DeLanda, M. 2006. A new philosophy of society: assemblage theory and social complexity. Bloomsbury: London.

DeLanda, M. 2011. Philosophy and simulation: the emergence of synthetic reason. Bloomsbury: London.

Gamble, L.H. 2008. Chumash architecture: sweat lodges and houses. Journal of California and Great Basin Anthropology 17:54-92 
Gamble, L.H. 2008. Chumash World At European Contact: Power, Trade, and Feasting Among Complex Hunter-Gatherers. University of California Press: Berkeley and Los Angeles.

Gayton, A.H. 1948. Yokuts and Western Mono ethnography 1: Tulare Lake, Southern Valley and Central Foothill Yokuts. Berkeley: University of California Press.

Gorenflo, L.J., and N. Gale.1990. Mapping regional settlement in information space. Journal of Anthropological Archaeology, 9(3), 240-274.

Graesch, A. P. 2004. Specialized bead making among Island Chumash households: community labor organization during the Historic Period. In J. Arnold (ed,), Foundations of Chumash Complexity. Los Angeles: UCLA Cotsen Insitute of Archaeology, 133-171.

Grasse, G. 2005. The Pleito Puzzle: An interim report on the excavations at CA-KER-77, Bakersfield, CA. Paper presented at the Society for California Archaeology General Meetings, Sacramento, California.

Herzog, I. 2012. The Potential and Limits of Optimal Path Analysis. https://www.academia.edu/download/30288111/Potential_Limits_LCP_rev2012.pdf. [accessed 20 December 2014].

Horne, S.P. 1981. The inland Chumash: ethnography, ethnohistory, and archaeology. Unpublished PhD Dissertation, University of California, Santa Barbara.

Horne, S.P. and Glassow, M. 1974. Archaeological Investigations, Sierra Madre Ridge, Los Padres National Forest.Manuscript on file, Los Padres National Forest.

Hudson, T. and T.C. Blackburn. 1983. The Material Culture of the Chumash Interaction Sphere: Volume II: Food Preparation and Shelter. Ballena Press: Menlo Park, California.

Hudson, T. and T.C. Blackburn. 1985. The Material Culture of the Chumash Interaction Sphere: Volume III: Clothing, Ornamentation, and Grooming. Ballena Press: Menlo Park, California.

Hudson, T. and T.C. Blackburn. 1987. The Material Culture of the Chumash Interaction Sphere: Volume V: Manufacturing Processes, Metrology, and Trade. Ballena Press: Menlo Park, California 
Hudson, T., and G. Lee. 1984. Function and Symbolism in Chumash Rock Art. Journal of New World Archaeology 6(3):26-47.

Hudson, T. and E. Underhay. 1978. Crystals in the Sky: An Intellectual Odyssey Involving Chumash Astronomy, Cosmology, and Rock Art. Ballena Press Anthropological Papers No. 10: Ballena Press/Santa Barbara Museum of Natural History: Santa Barbara.

Hyder, W.D. 1989. Rock art and archaeology in Santa Barbara County, California. San Luis Obispo: San Luis Obispo County Archaeological Society, 1-47.

Jackson, T.L. 1984. Predictive Model of Prehistoric Settlement Patterning in the Southern Sierra Neveda. In Cultural Resources Overview of the Southern Sierra Nevada, ed. Theodoratus Cultural Research and Archaeological Consulting and Research Services, Inc., 174-303. Prepard for USDA, South Central Contracting Office, Sierra National Forest, Fresno.

Jackson, T. L. 1991. Pounding Acorn: Women's Production as Social and Economic Focus. In Engendering Archaeology, Women and Prehistory, eds.J.M.. Gero and M.W. Conkey, 301325. Blackwell, Oxford.

Johnson, J.R., 1988. Chumash Social Organization: An Ethnohistorical Perspective. Unpublished PhD dissertation, Department of Anthropology: University of California Santa Barbara.

Johnson, J.R. 2001. Ethnohistoric Reflections of Cruzeño Chumash Society. In The origins of a Pacific Coast chiefdom: the Chumash of the Channel Islands, ed. J.E. Arnold, 301-325. University of Utah Press: Salt Lake City, 53-70.

Johnson, J.R., 2007. Ethnohistoric Descriptions of Chumash Warfare. In North American Indigenous Warfare and Ritual Violence, eds. R. Chacon, and R. Mendoza, 74-113. Tucson: University of Arizona Press.

Johnson, J. R., and R. Milliken. 2010a. San Emigdio Creek Region - Tashlipun Village Group. In Vol. 11, Santa Barbara Channel Analytical Zone, The Contact-Period Native California Community Distribution Model: A Dynamic Digital Atlas and Wiki Encyclopedia. Submitted to California Department of Transportation, District 6, Fresno. Davis: Far Western Anthropological Research Group. 
Johnson, J.R., and R. Milliken,. 2010b. Santiago Creek Region - Malapwan Local Band or Village. In Vol. 11, Santa Barbara Channel Analytical Zone, The Contact-Period Native California Community Distribution Model: A Dynamic Digital Atlas and Wiki Encyclopedia. Submitted to California Department of Transportation, District 6, Fresno. Davis: Far Western Anthropological Research Group.

Kennett, D. J. 2005. The Island Chumash: behavioral ecology of a maritime society. University of California Press: Berkeley.

King, C. 1975. The names and locations of Historic Chumash villages. Journal of California Anthropology 2(2),171-179.

King, C. 1976. Chumash inter-village economic exchange. In Native Californians: a theoretical perspective, eds. L.J. Bean and T.C. Blackburn, 288-318. Ballena Press: Romona, California.

King, C. 1990. Evolution of Chumash Society: A comparative study of artifacts used for social system maintenance in the Santa Barbara Channel Region before AD 1804. Garland Publishing: London and New York.

Kroeber, A.L. 1925. Handbook of the Indians of California. Bureau of American Ethnology

Bulletin 78. Washington, D.C.\#

Kroeber, A.L. 1955. Nature of the Land-Holding Groups. Ethnohistory 2(4):303-314.

Lightfoot, K. G., and O. Parrish. 2009. California Indians and Their Environment: An Introduction. University of California Press, Berkeley.

McLendon, S. and J.R. Johnson. 1999. Cultural affiliation and lineal descent of Chumash peoples in the Channel Islands and the Santa Monica Mountains. Report on file at the Archaeology and Ethnography Program, National Park Service, Washington, DC

Rick, T. 2007. Household and community archaeology at the Chumash village of Niaqla, Santa Rosa Island, California. Journal of Field Archaeology 32(3):243-263.

Robinson, D.W. 2006. Landscape, taskscape and indigenous perception: the rock-art of SouthCentral California. Unpublished $\mathrm{PhD}$ thesis, University of Cambridge. 
Robinson, D.W. 2007. Taking the Bight Out of Complexity: Elaborating South-Central California Interior Landscapes. In. Socialising Complexity: Structure, Integration, and Power, eds. S Kohrning and S. Wynne-Jones, 183-204. Oxbow: Oxford.

Robinson, D.W. 2010a. Land Use, Land Ideology: An Integrated Geographic Information Systems Analysis of Rock Art Within South-Central California. American Antiquity, 75(4): 792-818.

Robinson, D.W. 2010b. Resolving archaeological and ethnographic tensions: a case study from South-Central California. In Archaeology and Anthropology, eds.D. Garrow and T. Yarrow, 84-109.Oxbow: Oxford.

Robinson, D.W. 2011. Placing Ideology: Rock Art Landscape of Inland and Interior SouthCentral California. California Archaeology, 3(1), 31-52.

Robinson, D.W. and F. Sturt. 2008. Towards Articulating Rock Art with Archaeology: An Interim Report of the Pinwheel Cave Rock Art and Bedrock Mortar Complex (KER 5836 and 5837), Kern Country, California. Kern County Archaeological Society Journal 10, 25 44.

Robinson, D.W., F. Sturt and J. Bernard. 2010. Enculturating Environments: rock-art and the interior of South-Central California. Antiquity 84:232, Project Gallery, accessible at: http://antiquity.ac.uk/projgall/robinson323/

Robinson, D.W., W. Whitby, and M. Wienhold. 2012. California: from boundaries to networks. In Jones, Terry L. and Jennifer Perry (editors) Contemporary Issues in California Archaeology, pp. 273-293. Left Coast Press, Walnut Creek, California.

Schumacher, P. 1877. Researches in kjökkenmöddings and graves of a former population on the Santa Barbara Islands and the Adjacent Mainland. Bulletin of the United States Geological Survey 3(1):37-56.

Tobler, W. 1993. Three presentations on geographical analysis and modeling. National Center for Geographic Information and Analysis Technical Report 91-3. University of California Santa Barbara.

Tripcevich, N., 2009. Workshop 2009. No. 1 - Viewshed and Cost Distance. http://mapaspects.org/book/export/html/3743 [Accessed 20 December 2014].

Whitley, D. S., J.M. Simmon, and J.H.N. Loubser. 2006. The Carrizo Collapse: Art and Politics in the Past. In: A Festchrift Honoring the Contributions of California Archaeologist Jay 
Von Worlhoff, ed. R.L. Kaldenberg, 199-208. Ridgecrest: Maturango Museum Publications No. 20.

Wienhold, M.L. 2014. Spatial Analysis and Actor-Network Theory: A multi-scalar analytical study of the Chumash rock art of South-Central California. Unpublished Ph.D. thesis, University of Central Lancashire.

Zedeño M., and D. Anderson. 2010. Agency and politics in Hunter-Gatherer territory formation. Revista De Arqueologia 1:10-29.

\begin{tabular}{|c|c|c|c|c|c|c|c|c|c|}
\hline \multirow[b]{3}{*}{ Site Types } & \multicolumn{9}{|c|}{ Village Sites } \\
\hline & \multicolumn{3}{|c|}{ Matapuan } & \multicolumn{3}{|c|}{ Tashlipun } & \multicolumn{3}{|c|}{ Тесиуа } \\
\hline & $\begin{array}{c}4- \\
\text { Hour }\end{array}$ & $\begin{array}{c}- \\
\text { Hour }\end{array}$ & $\begin{array}{c}16- \\
\text { Hour }\end{array}$ & $\begin{array}{c}4- \\
\text { Hour }\end{array}$ & $\begin{array}{c}8- \\
\text { Hour }\end{array}$ & $\begin{array}{c}16- \\
\text { Hour }\end{array}$ & $\begin{array}{c}4- \\
\text { Hour }\end{array}$ & $\begin{array}{c}8- \\
\text { Hour }\end{array}$ & $\begin{array}{l}16- \\
\text { Hour }\end{array}$ \\
\hline K-locales & 3 & 5 & 13 & 2 & 8 & 14 & 1 & 6 & 15 \\
\hline $\begin{array}{l}\text { Pictograph } \\
\text { Sites }\end{array}$ & 3 & 10 & 16 & 2 & 12 & 18 & 1 & 6 & 17 \\
\hline BRM Sites & 15 & 27 & 49 & 16 & 29 & 50 & 7 & 30 & 49 \\
\hline Other Sites & 9 & 16 & 22 & 5 & 17 & 23 & 6 & 14 & 22 \\
\hline
\end{tabular}

TABLE 1: Number of site types per isochrone bin. Note that K-locales have large numbers of bedrock mortars (i.e. 18 or more) while BRM sites denotes bedrock mortar locations with fewer numbers (i.e. 17 or fewer). 


\begin{tabular}{|c|c|c|c|}
\hline \multirow[t]{2}{*}{ Pictograph site } & \multicolumn{3}{|c|}{ Village site } \\
\hline & Matapuan & Tashlipun & Tecuya \\
\hline Chimney & 58981.20703130000 & 36284.88671880000 & 94642.23437500000 \\
\hline Echo & 47623.21875000000 & 24926.89257810000 & 77337.07031250000 \\
\hline San Emigdio & 33841.71093750000 & 11145.39746090000 & 71416.39843750000 \\
\hline Letter & 41186.85546880000 & 18490.54101560000 & 78761.59375000000 \\
\hline Lizard & 42511.55859380000 & 19815.24804690000 & 78611.57812500000 \\
\hline Los Lobos & 27986.48437500000 & 30682.46875000000 & 90427.34375000000 \\
\hline Lonely Pine & 61628.81250000000 & 38932.49218750000 & 99203.87500000000 \\
\hline Lost Canyon & 80500.17187500000 & 58136.39062500000 & 72880.75781250000 \\
\hline Painted Petroglyph & 6339.88476563000 & 22843.58789060000 & 71486.42187500000 \\
\hline Pebble & 80914.25781250000 & 67688.05468750000 & 24643.51367190000 \\
\hline Pinwheel & 65500.97656250000 & 42804.65625000000 & 84139.85156250000 \\
\hline Pleito & 76124.58593750000 & 61846.02734380000 & 61490.47265630000 \\
\hline Pond & 37757.33593750000 & 15061.02343750000 & 75332.03906250000 \\
\hline Salt & 96223.09375000000 & 82996.57031250000 & 39951.82421880000 \\
\hline Santiago & 8707.67968750000 & 30910.51367190000 & 81747.62500000000 \\
\hline Tecuya & 113345.78125000000 & 100119.26562500000 & 40553.00781250000 \\
\hline Three Springs & 48868.76562500000 & 26172.44335940000 & 72442.67187500000 \\
\hline Total: & 3 & 10 & 4 \\
\hline
\end{tabular}

TABLE 2: ArcGIS least-cost path values from each village to each pictograph site. 
FIGURE 1: Map of the Emigdiano Chumash cultural landscape.

FIGURE 2: Matapuan isochrones representing 4-hour to 8-hour walking times (source map 10m DTM USGS).

FIGURE 3: Tashlipun isochrones representing 4-hour to 8-hour walking times (source map 10m DTM USGS).

FIGURE 4: Tecuya isochrones representing 4-hour to 8-hour walking times (source map 10m DTM USGS).

FIGURE 5: 4-hour isochrones from all three villages (source map 10m DTM USGS).

FIGURE 6: 8-hour isochrones from all three villages (source map 10m DTM USGS).

FIGURE 7: 12-hour isochrones from all three villages (source map 10m DTM USGS).

FIGURE 8: 16 -hour isochrones from all three villages (source map 10m DTM USGS).

FIGURE 9: Least-cost networks between villages and pictograph sites (source map 30m DTM USGS). 
